\title{
Effect of some biocontrol agents against root-knot nematode (Meloidogyne incognita race2)
}

\author{
Gitanjali Devi ${ }^{1}$ and L.C.Bora ${ }^{2}$
}

\author{
${ }^{1}$ Department of Nematology, ${ }^{2}$ Department of Plant-Pathology, Assam Agricultural University,Jorhat, India \\ Email:gitanjali_devi@yahoo.in
}

\begin{abstract}
Culture filtrate of four rhizospheric fungi and four biocontrol agents were studied in vitro for their efficacy against Meloidogyne incognita race 2. The per cent mortality and egg hatching inhibition was proportional to the concentration of culture filtrate and the duration of exposure period. Culture filtrates of Trichoderma viride, Trichoderma harzianum, Trichoderma sp., Fusarium sp., Penicillium sp. and Aspergillus sp. significantly induced inhibition of egg hatching and mortality of Meloidogyne incognita race 2.The highest percentage of inhibition of egg hatching and juvenile mortality was recorded in Trichoderma harzianum followed by Trichoderma viride and Trichoderma sp.
\end{abstract}

Keywords- Biocontrol agent, culture filtrate, egg hatching, juvenile mortality, root-knot nematode.

\section{INTRODUCTION}

Root-knot nematode (Meloidogyne spp.) is an important plant pathogen affecting crop production throughout the world. Since, indiscriminate use of nematicides is responsible for environmental and human health concerns; the search for new microbial strains as nematode control agents is relevant. As fungi cohabit together with nematodes in the rhizosphere, their toxic metabolites may be responsible for keeping a low level of ne matode populations [1]. The search for nematotoxic or antagonistic compounds in culture filtrates has greatly intensified in recent years, due to the number of toxins, enzymes or compounds derivable from their metabolites [2-7]. Assays with culture filtrates may provide first information about the role of a fungus in the plant rhizosphere, as in vitro studies showed toxic and inhibitory effects of several filtrates toward plant parasitic nematodes [8]. Toxic effects of fungal culture filtrates on $M$. incognita have been studied by several workers [9-16] and had showed different levels of efficacy [17-20]. Due to the differences of soil ecological types and climate, a broad range of fungi remains far unexplored. Therefore, present study was made to isolate rhizospheric fungal associations of root knot nematode infected plants and evaluate the potential of some isolated fungi and already recognized biocontrol agents (against insect pests and diseases) on hatching of eggs and mortality of secondstage juveniles of Meloidogyne incognita race 2 in vitro.

\section{MATERIALS AND METHODS}

\section{Collection of samples}

Soil samples were collected in different localities around Jorhat, Assam comprising an area approximately 1000 ha, in order to identify the root-knot nematode infection. To isolate the fungal antagonists from rhizosphere soils of infested cucurbits, tomato, brinjal, okra, cabbage, citrus, banana and tea, a total of 100 soil (500 g each) were collected. Samples were stored at $15^{\circ} \mathrm{C}$ for not more than one week.

\section{Fungal isolation and identification}

Soil mycoflora was isolated by serial dilution pour plate technique [21, 22]. One $g$ of rhizosphere soil was dispensed in $9 \mathrm{ml}$ sterile water, from the $10^{-5}$ dilution, $50 \mu \mathrm{l}$ were inoculated over Petri plates containing PDA media. The plates were incubated at room temperature $24 \pm 2^{\circ} \mathrm{C}$ for 48 hrs. Materials of the pure culture were mounted in Lactophenol, stained with Cotton blue and the morphological observations of hyphae, sporangiophore/conidiophores and conidia were done with the help of a Compound light microscope at $400 \mathrm{X}$ magnification [23, 24]. Axenic cultures of the fungi were obtained by single spore isolations [25] and the cultures were maintained on PDA slants. Trichoderma viride, Trichoderma harzianum, Beauveria bassiana, Metarhizium anisopliae were procured from the Department of Plant Pathology, AAU, Jorhat, Assam.

Nematode inoculum and mass culturing

The inoculum of root-knot nematode $M$. incognita race 2 was collected from naturally infested tomato crop in field and single egg mass was used to raise pure culture. Mass culturing of nematodes was done on tomato variety $\mathrm{Sel} 7$, in order to get regular supply of the inoculums for the experiment. One month old tomato seedlings were 
inoculated with small volume of egg suspension approximately consisting of 2000 eggs of M.incognita race 2. These pots were watered and kept in glasshouse at temperature $28-35^{\circ} \mathrm{C}$.

\section{Preparation of fungal culture filtrates}

To evaluate the nematicidal potential of the cell free fungal culture filtrate the most frequently occurring isolates belonging to the genera of Trichoderma, Aspergillus, Penicillium and Fusarium were selected. Beauveria bassiana, Metarhizium anisopliae, Trichoderma viride and Trichoderma harzianum were procured from the Department of Plant Pathology, AAU, Jorhat, Assam. These strains were inoculated on to Petri plates containing Potato Dextrose Agar medium and incubated for 7 to 10 days at $27^{\circ} \mathrm{C}$. From these actively growing cultures, one disc each of $0.5 \mathrm{~cm}$ diameter was transferred to $250 \mathrm{~mL}$ Erlenmeyer flask containing $50 \mathrm{~mL}$ Potato Dextrose broth. These flasks were incubated at $27 \pm 1^{\circ} \mathrm{C}$ for 15 days. The culture was filtered through two layers of Whatman filter Paper No.1. Filtrates thus obtained were designated as standard solution (100\%). Different dilutions (50\%, 25\%, and 10\%) of each fungal filtrate were prepared by adding required amount of sterilized distilled water.

\section{Hatching test}

To determine the effect of culture filtrate on the hatching of eggs of $M$. incognita sterilized Petri dishes of $5 \mathrm{~cm}$ dia were separately pipette two $\mathrm{ml}$ of culture filtrate. Five sterilized healthy egg masses of nearly uniform size of M.incognita were transferred to each dish. The egg masses placed in culture medium served as control. All Petri dishes were kept at $28 \pm 2^{\circ} \mathrm{C}$ in completely randomized design, replicated thrice. Observations were recorded on every $24 \mathrm{~h}$ interval up to $72 \mathrm{~h}$ with the aid of stereomicroscope. The per cent egg hatch was calculated by the following formula and mean of three replications was presented in Table.2.

No. of hatched juveniles

Hatching \%= ------------------ $\mathrm{x}$

100

No. of hatched+ unhatched eggs

\section{Mortality of second stage juveniles ( $\mathrm{J} 2)$}

For determining the effect of fungal filtrates on juvenile mortality of M.incognita race 2, egg masses were collected from an infested root and allowed to hatch in distilled water with aeration. The hatched $\mathbf{J}_{2}$ were collected in a beaker. One hundred freshly hatched second stage juveniles were transferred to $5 \mathrm{~cm}$ dia Petri dishes containing $2 \mathrm{ml}$ filtrates of different dilutions of each fungus and medium separately. Equal number of $\mathbf{J}_{2}$ was also transferred to separate Petri dishes containing culture medium to serve as control. Petri dishes were kept at $28 \pm 2^{\circ} \mathrm{C}$ temperature in completely randomized design, replicated thrice. Observation on the number of dead $\mathrm{J}_{2}$ for every 24,48 and $72 \mathrm{~h}$ of exposure was recorded with the aid of stereomicroscope and per cent mortality of juveniles was calculated. The $\mathrm{J}_{2}$ were considered dead when they did not move when probing with a fine needle Mean percentage of dead $\mathbf{J}_{2}$ was estimated using the following formula and presented in the Table 3.

Total number of dead juveniles

Per cent mortality= ----------------- x100

Total number of juveniles

STATISTICAL ANALYSIS

Per cent egg hatch and per cent mortality data was subjected to statistical analysis using the three factorial completely randomized design statistical package. The critical differences in main effects i.e. isolates, concentration, and time of exposure as well as in their interactions were tested at $\mathrm{P}=0.05$.

\section{RESULTS}

A total of four isolates of different genera of fungi were isolated from the soil rhizosphere of M.incognita race 2 infected plants. Trichoderma sp. Fusarium sp., Aspergillus sp. and Penicillium sp. was isolated from rhizospheric soil of banana, cowpea, brinjal and cucumber respectively.

The results presented in Table 1 revealed significant differences among isolates (biocontrol agent) (T), concentration of culture filtrate $(\mathrm{C})$ and exposure period(t). The culture filtrate of Trichoderma harzianum followed by T.viride, T.sp. Aspergillus sp., P. sp. and F.sp. adversely affected the larval hatching of M.incognita race 2 . Irrespective of concentration of culture filtrate $(C)$ and time of exposure period (t), T.harzianum was the most effective bioagent followed by T.viride and T.sp. as the hatching of M.incognita was suppressed. Similarly, irrespective of is olate (biocontrol agent) (T) and concentration of culture filtrate (C), time of exposure(t) also affected the larval hatching. With increase in exposure period up to 72 hours there was a correspondingly increased in egg hatching. With increase in the dilution of culture filtrate, the cumulative hatching was increased irrespective of isolate (T) and time of exposure period (t). Highest inhibition in hatching was obtained in $100 \%$ concentration of each fungal culture filtrates. The percentage hatching of M.incognita was $18.35 \%$ during $72 \mathrm{~h}$ exposure in the $100 \%$ concentrations of culture filtrates of Trichoderma viride followed by T.harzianum with percentage hatching $20.36 \%$. Beauveria bassiana and Metarhizium anisopliae showed negligible 
effect on inhibition of egg hatching of M.incognita. Hatching percentage was $59.34 \%, 58.35 \%$ respectively at $10 \%$ concentration of culture filtrate during $72 \mathrm{~h}$ exposure period.

The data showed in the Table 2 revealed that all the culture filtrates of isolates were having nematicidal effect of varying degree on M.incognita race 2. Per cent mortality of nematodes was directly proportional to the concentration of culture filtrate and the period of exposure. Irrespective of concentration of culture filtrate (C) and duration of exposure(t), six isolates namely Trichoderma harzianum, Trichoderma viride, Trichoderma sp., Fusarium sp., Aspergillus sp. and Penicillum sp. were exhibited nematicidal effects on $M$. incognita $\mathrm{J}_{2}$. The activity of Trichoderma harzianum was the highest, with juvenile mortality $82.66 \%, 85.33 \%, 89.33 \%$ for 24,48 and $72 \mathrm{~h}$, respectively at $100 \%$ concentration of culture filtrate. This was followed by T.viride with juvenile mortality $79.00 \%$, $81.66 \%, 85.66 \%$ for 24,48 and $72 \mathrm{~h}$, respectively at $100 \%$ concentration of culture filtrate. All the new isolate namely Trichoderma sp., Penicillum sp., Aspergillus sp., and Fusarium sp. displayed more than 50\% juvenile mortality during $24 \mathrm{~h}$ exposure time at $25 \%$ concentration of culture filtrate. On the other hand, Beauveria bassiana and Metarhizium anisopliae showed the lowest toxicity, caused only $67.66 \%$ and $51.65 \%$ juvenile mortality at $50 \%$ concentration of culture filtrate during $72 \mathrm{~h}$ exposure time.

\section{DISCUSSION}

Culture filtrates of many fungi possess nematicidal activity against nematodes, due to the production of toxic metabolites [26].Variable effect of fungal filtrates on hatching and mortality of root-knot nematode M.incognita race 2 observed in the present study may be attributed to the varied nature of toxic metabolites produced by different fungi. Species of Trichoderma, Fusarium, Paecilomyces, Aspergillus, Penicillium are known to produce toxins and antibiotics like viridian, fusaric acid, lilacin, oxalic acid and penicillic acid [27, 28]. Various mechanis ms have been suggested for the biocontrol activity of Trichoderma spp. against phytopathogenic fungi: antibiosis, competition, mycoparasitism, and enzymatic hydrolysis [29, 30]. Trichoderma spp. is utilized in the production of a number of antibiotics, such as trichoderin, trichodermol $\mathrm{A}$ and harzianolide. Trichoderma produces molecules such as 6pentyl $\alpha$-pyrone, VOCs and enzy mes [31] that can attack the cuticle of nematodes. Also, its hyphae form a physical barrier, which is a difficult step for nematodes, since the fungus grows along with the plant roots. Successful parasitism of the nematode by Trichoderma requires mechanisms to facilitate penetration of the nematode cuticles or eggshells. The involvement of lytic enzy mes has long been suggested and demonstrated in Meloidogyne parasitism [32]. Besides direct antagonism, other mechanisms involved in Meloidogyne control by Trichoderma spp. include production of fungal metabolites and induced resistance [33-35]. Trichoderma harzianum has been found to be an effective biocontrol agent for the management of root-knot and other nematodes [36-39]. Direct interactions between $T$. harzianum and the potato cyst nematode Globodera rostochiensis were demonstrated in vitro by Saifullah and Thomas [40].The fungus penetrated the cysts and the eggs in those cysts, resulting in larval death. Beauveria bassiana has a repressive action on nematodes of the genus Meloidogyne spp. [41-47]. $B$. bassiana may have more than a single bioactive metabolite that are responsible for nematicidal activities, and each metabolite may act on a different site. Ghayedi and Abdollahi [48] purified the isolated fungus and also they showed the biocontrol potential of the isolate on Heterodera avenae, with $47.1 \%$ of larval mortality. Chen et al., [49] found that B. bassiana showed little parasitism of nematode eggs but reduced hatch of Heterodera glycines. Studies have shown that Beauveria can produce beauvericin and oosporin. Beauvericin has a weak activity against $M$. incognita [50-53]. The percentage mortality and inhibition of hatching of root-knot nematode were directly proportional to the concentration of culture filtrates of B.bassiana [54]. Biocontrol potential of M. anisopliae against some species of root knot nematodes has been shown [55-58]. The lethal effect of $M$. anisopliae culture extract has been also reported [59]. Some species of Metarhizium has root colonization ability [60, 61]. Some isolates of M. anisopliae have endophytic behavior [62]. The fungus produces sticky conidia that attach to nematode cuticle [63]. The conidia germinate, parasitize and kill the cadaver, by direct penetration and producing the infective hyphae inside the nematode body. The fungus produces some cyclopeptides and destruxins which may play an important role in its pathogenicity [64]. Prior to any direct attack to the host, the fungus produces destruxin $\mathrm{A}$ and destruxin B that can kill the host [65].

\section{CONCLUSION}

It is clear from this work that, in plant rhizosphere, there are many fungi that have potentialities for controlling root-knot nematode. Among four fungal isolates and four bioagents, Trichoderma harzianum was exhibited the highest 
production of nematicidal activities against root-knot nematode ( $M$. incognita race 2$)$ in vitro.

\section{REFERENCES}

[1].Kerry, B.R. 2000. Rhizosphere interactions and the exploitation of microbial agents for the biological control of plant-parasitic nematodes. Annual Review of Phytopathology 38:423-441

[2].Ciancio, A. 1995 Observations on the nematicidal properties of some mycotoxins. Fundamental and Applied Nematology 18:451-454

[3].Liu, T., Wang, L., Duan, Y.X. and Wang, X. 2008. Nematicidal activity of culture filtrate of Beauveria bassiana against Meloidogyne hapla. World Journal of Microbiology and Biotechnology 24:113-118

[4].Lopez-Llorca, L.V., Macia-Vicente, J.G. and Jansson, H.B. 2008. Mode of action and interactions of nematophagous fungi. p. 49-74 In Ciancio $\mathrm{A}$ and Mukerji KG (Eds.). Integrated management and biocontrol of vegetable and grain crops nematodes. Springer, NL.

[5].Khan,TA., Hussain,SI.and Azam,M.F.1984. Effect of culture filtrates of eight species of Aspergillus on the hatching and mortality of Meloidogyne incognita.Indian Journal of Nematology 14:51-54.

[6].ReddyKumar, M., Sailaja Rani, J. and John Sudheer, M.2007. Effect of opportunistic fungi on eggmass parasitization and mortality of juveniles of Meloidogyne incognita in vitro. Indian Joumal of Nematology 37(2): 127-130.

[7].Shinya, R., Aiuchi, D., Kushida, A., Tani, M., Kuramochi, K. and Koike, M.2008.Effect of fungal culture filtrates of Verticillium lecanii(Lecanicillium spp.) hybrid strains on Heterodera glycines eggs and juveniles. Journal of Invertebrate Patholology 97:291297

[8].Nitao, J.K., Meyer, S.L.F.and Chitwood, D.J. 1999. In vitro assays of Meloidogyne incognita and Heterodera glycines for detection of nematode-antagonistic fungal compounds. Journal of Nematology 31:172-183

[9].Hallmann, J. and Sikora, R.A. 1996. Toxicity of fungal endophyte secondary metabolites to plant parasitic nematodes and soil-borne plant pathogenic fungi. European Journal of Plant Pathology 102: 155-162.

[10]. Anke, H. and Sterner, O. 1997. Nematicidal metabolites from higher fungi. Current Organic Chemistry 1: 361-374

[11].Sharma, D.D., 1999. Effect of culture filtrates of biocontrol agents on larval mortality of Meloidogyne incognita in comparison with Rugby10G. Indian Journal of Sericulture 38: 152-154.

[12].Wang, L., Yang B. and Li, C. 1999. Evaluation of pathogenicity of parasitic fungi to root-knot nematodes. Scientia Silvae Sinicae 35:41-47

[13].Costa, M.J.N., Campos, V.P., Pfenning L.H. and Oliveira, D.F 2000. Pathogenicity and reproduction of Meloidogyne incognita in tomato plants (Lycopersicon esculentum) with application of fungal filtrates or plant and animal manure extracts. Nematologica Brasileira 24: 219-226.

[14].Randhawa, N., Singh, P. , Sandhu, K.S. and Bhatia, A. 2001. Effect of culture filtrates of soil fungi on hatching of Meloidogyne incognita. Plant Disease Research 16: 280-282.

[15].Meyer, S.L.F., Huettel, R.N., Liu, X.Z., Humber, R.A., Juba, J. and Nitao, J.K. 2004. Activity of fungal culture filtrates against soybean cyst nematode and root-knot nematode egg hatch and juvenile motility. Nematology 6: 23-32.

[16].Zareen, A., Aleem, F. Zaki, M.J., Shaukat, S.S. and Siddiqui, I.A. 2001. Observations on the nematicidal effect of Fusarium solani on the root-knot nematode Meloidogyne javanica [Lycopersicon esculentum Mill.]. Journal of Plant Pathology 83: 207-214.

[17].Chen, F. and Chen, S. 2002. Mycofloras in cysts, females, and eggs of the soybean cyst nematode in Minnesota.Applied Soil Ecology 19:35-50

[18].Olivares-Bernabeu, C.M.and Lopez-Llorca, L.V. 2002. Fungal egg-parasites of plant-parasitic nematodes from Spanish soils. Revista Iberoamericana de Micologia 19:104-110.

[19].Mukhtar, T. and Pervaz, I. 2003. In vitro evaluation of ovicidal and larvicidal effects of culture filtrate of Verticillium chlamydosporium against Meloidogyne javanica. International Journal of Agriculture and Biology 4:576-579.

[20].Khan, A., Williams, K.L.and Nevalainen, H.K.M. 2004.Effects of Paecilomyces lilacinus protease and chitinase on the eggshell structures and hatching of Meloidogyne javanica juveniles. Biological Control 31:346-352

[21]. Johnson,L.F.a nd Curl,E.A.1972. Methods of Research on the Ecology of soil Borne Plant Pathogens. p.6-8. Burgess Publishing Company, Minnesota,.

[22].Aneja, K.R. 2003. Experiments in Microbiology, Plant Pathology and Biotechnology. 4th Edn., p. 363-379 New Age International Publishers, New Delhi, India. 
[23].Barnett,H.L.1962. Illustrated genera of imperfect fungi. p.225. Burgess Publishing Corporation, Minneapolis, USA.

[24].Subramanian,C.V.1971. Hyphomycetes an account of Indian species except Cercospora. Indian Council of Agricultural Research, New Delhi.

[25].Johnston, A. and Booth,C.1983. CMI Plant Pathologist pocket book. p .439 Common Wealth Agricultural Bureaux,UK.

[26].Sayre,R.M.1971. Biotic influences in soil environment. p. 235-256. In Zuckerman, W.F.Mai and R.A.Rohde (Eds.). Plant Parasitic Nematodes, Vol.I B.N..Academic Press, New York.

[27].Desai,M.V., Shah,H.M. and Pillai,S.N.1972. Effect of Aspergillus niger on root-knot nematode,Meloidogyne incognita.Indian Journal of Nematology 2: 210-214.

[28]. Anke, H. and Sterner, O. 1997. Nematicidal metabolites from higher fungi. Current Organic Chemistry 1: 361-374

[29].Widden, P. and Abitbol, J.J. 1980 Seasonality of Trichoderma species in a spruce forest soil. Mycologia 72 (4): 775-784.

[30].Gonzalez, I., Infante, D., Martinez, B., Arias, Y., Gonzalez, N., Miranda, I.and Peteira, B. 2012. Induction of chitinases and glucanases in Trichoderma spp. Strains intended for biological control. Biotecnology and Applied Biochemistry 29: 12-16

[31].Samson, R.A., Hoekstra, E.S., Frisvad, J.C. and Filtenborg, O. 1996.Introduction to food borne fungi. Fifth edition. CBS, Netherlands.

[32].Spiegel, Y., Sharon, E. and Chet, I. 2005. Mechanisms and improved biocontrol of the root-knot nematodes by Trichoderma spp. Acta Horticulturae 698: $225-228$.

[33].Samuels, G.J. 1996. Trichoderma: a review of biology and systematics of the genus. Mycological Research 100: $923-935$.

[34].Harman, G.E. 2000 Changes in perceptions derived from research on Trichoderma harzianum T22. Plant Disease 84 (4): 377-393.

[35].Goswami, J., Pandey, R.K. Tewari, J.P. and Goswami, B.K. 2008. Management of root- knot nematode on tomato through application of fungal antagonists, Acremonium strictum and Trichoderma harzianum. Journal of Environmental Science and Health 43: 237-240.

[36].Casas-Flores, S. and Herrera-Estrella, A. 2007. Antagonism ofplant parasitic nematodes by fungi. p. 147-157. In C.P.Kubicek and I.S. Druzhinina(eds.).
The Mycota, Vol.VI: Environmental and Microbial Relationships, 2nd Edn. Springer-Verlag, Berlin.

[37].Lopez Llorca, L.V., Macia Vicente, J.G. and Jansson, H.B. 2008. Mode of action and interactions of nematophagous fungi. P. 49-74. In Ciancio A, Mukerji KG (Eds.). Integrated management and biocontrol of vegetable and grain crops nematodes. Springer, NL.

[38].Hallmann, J., Davies, K.G. and Sikora, R.A. 2009. Biologicalcontrol using microbial pathogens, endophytes and antagonists. p. 380-411.In R.N. Perry, M. Moens and J.L.Starr, (eds.). Root-Knot Nematodes .CABI Publishing, Wallingford, UK.

[39].Moosavi, M.R. and Zare, R. 2012. Fungi as biological controlagents of plant-parasitic nematodes.p. 67-107. In J.M. Merillon and K.G. Ramawat (Eds.). Plant Defence: Biological Control.Springer Science Business Media, Dordrecht.

[40].Saifullah and Thomas,B.J.1996.Studies on the parasitism of Globodera rostochiensis by Trichoderma harzianum using low temperature scanning electron microscopy. Afro-Asian Journal of Nematology 6: 117-122.

[41].Bradley, C.A., Black, W.E., Kearns, R.and Wood, P. 1992.Role of production technology in mycoinsecticide development, pp. 160-173. In G. E. Leatham (ed.), Frontiers in industrial microbiology. Chapman and Hall, New York.

[42].Bekanayake HMRK, Jayasundar NJ. 1994. Effect of Paecilomyces lilacinus and Beauveria bassiana in controlling Meloidogyne incognita on tomato in Sri Lanka. Nematologia Mediterranea 22:87-88.

[43].Feng, M.G., Chen, B. and Ying, S.H. 2004. Trials of Beauveria bassiana, Paecilomyces fumosoroseus and imidacloprid for management of Trialeurodes vaporariorum (Homoptera: Aleyrodidae) on greenhouse grown lettuce. Biocontrol Science and Technology 14:489-496.

[44].Hatting, J.L., Wraight, S.P.and Miller, R.M. 2004. Efficiency of Beauveria bassiana (Hyphomycetes) for control of Russian wheat aphid (Ho moptera:Aphididae) on resistant wheat under field conditions. Biocontrol Science and Technology 14:459-473.

[45].Jean, P.K., Les, S., Peter, K., and Bruce, B. 2008. Optimal concentration of Beauveria bassiana vectored by bumble bees in relation to pest and bee mortality in greenhouse tomato and sweet pepper. Biocontrol 53:797-812. 
[46].Caroppo, S., Perito, B.and Pelagatti, O. 1990. In vitro evaluation of nematicide activity by several fungi against Meloidogyne incognita eggs. Redia 73:451462.

[47].Lin, D., Dehai, L., Tianjiao, Z. 2009. New alkaloids and diterpenes from a deep ocean sediment derived fungus Penicillium sp. Tetrahedron 65(5):1033-1039.

[48].Ghayedi, S. and Abdollahi, M. 2013. Biocontrol potential of Metarhizium anisopliae (Hypocreales: Clavicipitaceae), isolated from suppressive soils of Boyer-Ah mad region, Iran, against $\mathrm{J}_{2 \mathrm{~S}}$ of Heterodera avenae. Journal of Plant Protection Research 53 (2): 165-171.

[49].Chen, S.Y., Dickson, D.W.and Mitchell, D.J. 1996. Pathogenicity of fungi to eggs of Heterodera glycines. Journal of Nematology 28(2):148-158.

[50].Hamil, P.L., Higgeus, C.E., Boan, H.E. 1969. The structure of Beauvericin, A new depsipepdicle antibiotic toxic to Artemia salina. Tetrahedron Letters 49:4255-4258.

[51].Suzuki, A., Kanaoka, M.and Isogai,A. 1977. Bassianolide, a new insecticidal cyclodepsipeptide from Beauveria bassiana and Verticillium lecanii. Tetrahedron Letters 25:2167-2170.

[52].Anke, H., Stadler, M. and Mayer,A. 1995. Secondary metabolites with nematicidal and antimicrobial activity from nematophagous fungi and ascomycetes. Canadian Journal of Botany 72(SI):932-939.

[53].Mayer, A. 1995. PhD Thesis, University of Kaiserslautern, Kaiserslautern, Germany.

[54].Zhao, D., Liu,B., Wang,Y., Zhu,X, Duan,Y and Chen,L.2013.Screening for nematicidal activities of Beauveria bassiana and associated fungus using culture filtrate. African Journal of Microbiology Research 7(11).974-978.

[55].Mahmoud, M.F. 2009 Pathogenicity of three commercial products of entomopathogenic fungi, Beauveria bassiana, Metarhizum anisopilae and Lecanicillium lecanii against adults of olive fly, Bactrocera oleae (Gmelin) (Diptera:Tephritidae) in the laboratory. Plant Protection Science 45 (3): 98-102

[56].Jahanbazian, L., Abdollahi, M., and Hussienvand, M. 2014. Inhibitory effect of Metarhizium anisopliae against Meloidogyne incognita, the causal agent of root knot of tomato, under laboratory condition.
National Conference of Modern Topic in Agriculture. March 6, 2014,Tehran, Iran.

[57].Khosrawi, M., Abdollahi, M. and Sadravi, M. 2014. Effect of Metarhizium anisopliae and Trichoderma harzianum on root knot nematode, Meloidogyne javanica. Biological Control of Pests and Plant Diseases 3(1): 67-76.

[58].Jahanbazian, L., Abdollahi, M., and Rezaie, R. 2015. Combined effect of Metarhizium anisopliae and Pseudomonas fluorescens CHA 0 on root-knot nematode, Meloidogyne incognita in tomato. Iranian Journal of Plant Pathology 51(3): 339-355.

[59].Mohanty, S. S., Raghavendra, K.,Mittal, P. K. and Dash, A. P. 2008. Efficacy of culture filtrates of Metarhizium anisopliae against larvae of Anopheles stephensi and Culex quinquefasciatus. Journal of Industrial Microbiology and Biotechnology 35: 11991202.

[60].Bruck, D. J. 2005. Ecology of Metarhizium anisopliae in soilless potting media and the rhizosphere: implications for pest management. Biological Control 32: $155-163$

[61].Wang, C. and St Leger, R. J. 2007.The MAD1 adhesion of Metarhizium anisopliae links adhesion with blastospore production and virulence to insects, and the MAD2 adhesion enables attachment to plants. Eukaryote Cell 6: 808-816.

[62].St Leger, R. 2008. Studies on adaptations of Metarhizium anisopliae to life in the soil. Journal of Invertebrate Pathology 98: 271-276.

[63].Ghayedi, S. and Abdollahi, M. 2013. Biocontrol potential of Metarhizium anisopliae (Hypocreales: Clavicipitaceae), isolated from suppressive soils of Boyer-Ah mad reg ion, Iran, against J2s of Heterodera avenae. Journal of Plant Protection Research 53 (2): 165-171.

[64].Kershaw, M. J., Moorhouse, E. R.,Bateman, R., Reynolds, S. E. and Charnley, A. K. 1999. The Role of destruxins in the pathogenicity of Metarhizium anisopliae for three species of insect. Journal of Invertebrate Pathology 74: 213-223.

[65].Roberts, D. W. 1966. Toxins from the entomogenous fungus Metarhizium anisopliae. 1. Production insubmerged and surface cultures, and in inorganic and organic nitrogen media. Journal of Invertebrate Pathology 8: 212-221. 
Table.1: Effect of culture filtrate of some fungal bioagent on egg hatching of Meloidogyne incognita race 2.

\begin{tabular}{|c|c|c|c|c|c|c|}
\hline \multirow[t]{2}{*}{ Is olate(T) } & \multirow{2}{*}{$\begin{array}{l}\text { Culture } \\
\text { filtrate } \\
\text { concentration } \\
\text { (C) }(\%)\end{array}$} & \multicolumn{3}{|c|}{ Period of exposure(t) } & \multirow{2}{*}{$\begin{array}{l}\text { Isolate } \\
\text { (T) } \\
\text { Mean }\end{array}$} & \multirow{2}{*}{$\begin{array}{l}\text { Culture filtrate } \\
\text { concentration } \\
\text { ( C ) } \\
\text { Mean }\end{array}$} \\
\hline & & $24 \mathrm{~h}$ & $48 \mathrm{~h}$ & $72 \mathrm{~h}$ & & \\
\hline \multirow[t]{4}{*}{ Trichoderma sp. } & 10 & $24.35(29.53)$ & $32.33(34.64)$ & $40.35(39.38)$ & \multirow{4}{*}{$\begin{array}{c}24.19 \\
(29.06)\end{array}$} & $40.11(39.22)$ \\
\hline & 25 & $20.34(26.79)$ & $28.34(32.14)$ & $34.35(35.84)$ & & $34.82(35.93)$ \\
\hline & 50 & $16.33(23.70)$ & $22.35(28.17)$ & $26.32(30.86)$ & & $28.32(31.74)$ \\
\hline & 100 & $10.30(18.66)$ & $12.30(20.53)$ & $22.65(28.41)$ & & $20.91(26.39)$ \\
\hline \multirow[t]{4}{*}{ Penicillium sp. } & 10 & $28.32(32.11)$ & $34.30(35.82)$ & $46.36(42.89)$ & \multirow{4}{*}{$\begin{array}{c}25.34 \\
(30.33)\end{array}$} & \\
\hline & 25 & $20.35(26.79)$ & $30.65(33.62)$ & $38.32(38.21)$ & & \\
\hline & 50 & $18.34(25.15)$ & $24.30(29.54)$ & $28.30(32.15)$ & & \\
\hline & 100 & $10.30(18.71)$ & $14.32(22.20)$ & $20.30(26.73)$ & & \\
\hline \multirow[t]{4}{*}{ Aspergillus sp. } & 10 & $28.30(32.06)$ & $34.33(35.85)$ & $43.34(41.16)$ & \multirow{4}{*}{$\begin{array}{c}24.74 \\
(29.92)\end{array}$} & \\
\hline & 25 & $22.35(28.17)$ & $28.34(32.04)$ & $38.35(38.22)$ & & \\
\hline & 50 & $16.35(23.70)$ & $24.35(29.49)$ & $26.33(30.86)$ & & \\
\hline & 100 & $10.33(18.66)$ & $12.30(20.49)$ & $22.32(28.19)$ & & \\
\hline \multirow[t]{4}{*}{ Fusarium sp. } & 10 & $26.32(30.81)$ & $34.30(35.85)$ & $44.36(41.74)$ & \multirow{4}{*}{$\begin{array}{c}26.16 \\
(30.53)\end{array}$} & \\
\hline & 25 & $22.32(28.17)$ & $30.35(33.37)$ & $38.32(38.23)$ & & \\
\hline & 50 & $16.30(23.73)$ & $24.35(29.54)$ & $28.35(32.14)$ & & \\
\hline & 100 & $12.32(19.91)$ & $14.32(22.20)$ & $22.34(28.17)$ & & \\
\hline \multirow{4}{*}{$\begin{array}{l}\text { Trichoderma } \\
\text { viride }\end{array}$} & 10 & $25.33(30.18)$ & $30.30(33.41)$ & $42.30(40.58)$ & \multirow{4}{*}{$\begin{array}{c}23.74 \\
(28.63)\end{array}$} & \\
\hline & 25 & $20.34(26.78)$ & $28.35(32.08)$ & $36.32(37.05)$ & & \\
\hline & 50 & $12.30(20.53)$ & $22.32(28.19)$ & $26.35(30.85)$ & & \\
\hline & 100 & $8.30(16.53)$ & $14.35(22.20)$ & $18.35(22.44)$ & & \\
\hline \multirow{4}{*}{$\begin{array}{l}\text { Trichoderma } \\
\text { harzianum }\end{array}$} & 10 & $22.30(28.17)$ & $30.30(33.40)$ & $36.34(37.05)$ & \multirow{4}{*}{$\begin{array}{c}22.00 \\
(27.59)\end{array}$} & \\
\hline & 25 & $18.34(25.12)$ & $26.30(30.85)$ & $30.35(33.36)$ & & \\
\hline & 50 & $14.35(22.19)$ & $20.35(26.77)$ & $22.35(28.19)$ & & \\
\hline & 100 & $10.35(18.66)$ & $12.35(20.42)$ & $20.36(26.79)$ & & \\
\hline \multirow{4}{*}{$\begin{array}{l}\text { Beauveria } \\
\text { bassiana }\end{array}$} & 10 & $33.60(35.45)$ & $42.32(40.58)$ & $59.34(50.39)$ & \multirow{4}{*}{$\begin{array}{c}33.53 \\
(35.12)\end{array}$} & \\
\hline & 25 & $28.30(32.11)$ & $38.32(38.23)$ & $46.32(42.89)$ & & \\
\hline & 50 & $24.32(29.54)$ & $34.30(35.85)$ & $32.30(34.64)$ & & \\
\hline & 100 & $18.62(25.33)$ & $20.30(26.77)$ & $24.34(29.53)$ & & \\
\hline \multirow{4}{*}{$\begin{array}{l}\text { Metarhizium } \\
\text { anisopliae }\end{array}$} & 10 & $33.65(35.45)$ & $42.32(40.58)$ & $58.35(49.79)$ & \multirow{4}{*}{$\begin{array}{c}33.60 \\
(35.16)\end{array}$} & \\
\hline & 25 & $30.32(33.40)$ & $36.32(37.05)$ & $46.34(42.89)$ & & \\
\hline & 50 & $26.30(30.85)$ & $32.35(34.64)$ & $32.35(34.64)$ & & \\
\hline & 100 & $16.30(23.70)$ & $20.35(26.77)$ & $28.36(32.12)$ & & \\
\hline \multirow[t]{4}{*}{ Culture broth } & 10 & $51.00(45.57)$ & $74.34(59.57)$ & $84.37(66.70)$ & \multirow{4}{*}{$\begin{array}{c}64.41 \\
(53.74)\end{array}$} & \\
\hline & 25 & $50.00(44.98)$ & $72.65(58.52)$ & $79.38(62.96)$ & & \\
\hline & 50 & $48.33(44.04)$ & 67.34(55.15) & $77.30(61.58)$ & & \\
\hline & 100 & $45.00(42.12)$ & $55.65(48.24)$ & $67.65(55.34)$ & & \\
\hline $\begin{array}{l}\text { Period of } \\
\text { Exposure (t) Mean }\end{array}$ & & $23.36(28.27)$ & $31.19(33.47)$ & $38.60(38.22)$ & & \\
\hline \multicolumn{7}{|c|}{$\begin{array}{l}\mathrm{CV}=6.92 \\
\mathrm{CD}(\mathrm{P}=0.05) \text { : } \\
\text { Treatment }(\mathrm{T}): 1.06 ; \text { Concentration }(\mathrm{C}): 0.71 ; \text { Period of exposure }(\mathrm{t}): 0.61 ; \\
\mathrm{T} \times \mathrm{C}: 2.13 ; \mathrm{T} \times \mathrm{t}: 1.84 ; \mathrm{C} \times \mathrm{t}: 1.23 ; \mathrm{T} \times \mathrm{C} \times \mathrm{t}: 3.69\end{array}$} \\
\hline
\end{tabular}

Figures in the parentheses are Arc-Sine transformed values 
Table.2: Effect of culture filtrate of some fungal bioagent on juvenile mortality of Meloidogyne incognita race 2.

\begin{tabular}{|c|c|c|c|c|c|c|}
\hline \multirow{2}{*}{$\begin{array}{l}\text { Is olate } \\
\text { (T) }\end{array}$} & \multirow[b]{2}{*}{$\begin{array}{l}\text { Culture } \\
\text { filtrate } \\
\text { concentration } \\
\text { (C) } \\
(\%)\end{array}$} & \multicolumn{3}{|c|}{ Period of exposure(t) } & \multirow{2}{*}{$\begin{array}{c}\text { Is olate } \\
(\mathrm{T}) \\
\text { Mean }\end{array}$} & \multirow{2}{*}{$\begin{array}{c}\text { Culture filtrate } \\
\text { concentration } \\
\text { ( C) } \\
\text { Mean }\end{array}$} \\
\hline & & $24 \mathrm{~h}$ & $48 \mathrm{~h}$ & $72 \mathrm{~h}$ & & \\
\hline \multirow[t]{4}{*}{ Trichoderma sp. } & 10 & $44.66(41.92)$ & $47.62(43.65)$ & $51.60(45.95)$ & \multirow{4}{*}{$\begin{array}{c}65.11 \\
(54.08)\end{array}$} & $45.00(41.98)$ \\
\hline & 25 & $61.60(51.75)$ & $65.64(54.14)$ & $71.66(57.86)$ & & $56.98(49.07)$ \\
\hline & 50 & $63.62(52.94)$ & $69.65(56.62)$ & $77.64(61.80)$ & & $60.72(51.39)$ \\
\hline & 100 & $68.65(55.97)$ & $77.66(61.86)$ & $81.33(64.42)$ & & $66.09(54.96)$ \\
\hline \multirow[t]{4}{*}{ Penicillium sp. } & 10 & $38.67(38.42)$ & $44.66(41.93)$ & $50.60(45.38)$ & \multirow{4}{*}{$\begin{array}{c}55.36 \\
(48.13)\end{array}$} & \\
\hline & 25 & $51.66(45.95)$ & $54.66(47.67)$ & $57.66(49.40)$ & & \\
\hline & 50 & $54.66(47.67)$ & $59.62(50.57)$ & $61.60(51.75)$ & & \\
\hline & 100 & $57.33(49.22)$ & $65.60(54.13)$ & $67.64(55.39)$ & & \\
\hline \multirow[t]{4}{*}{ Aspergillus sp. } & 10 & $41.67(40.19)$ & $50.66(45.37)$ & $53.66(47.09)$ & \multirow{4}{*}{$\begin{array}{c}62.71 \\
(52.52)\end{array}$} & \\
\hline & 25 & $60.34(50.96)$ & $63.66(52.93)$ & $67.66(55.34)$ & & \\
\hline & 50 & $61.34(51.56)$ & $65.66(54.14)$ & $69.66(56.62)$ & & \\
\hline & 100 & $67.33(55.24)$ & $73.66(59.14)$ & $77.33(61.56)$ & & \\
\hline \multirow[t]{4}{*}{ Fusarium sp. } & 10 & $39.33(38.82)$ & $43.66(41.35)$ & $49.66(44.80)$ & \multirow{4}{*}{$\begin{array}{c}63.71 \\
(53.23)\end{array}$} & \\
\hline & 25 & $60.33(50.98)$ & $67.66(55.36)$ & $69.66(56.65)$ & & \\
\hline & 50 & $64.66(53.54)$ & $69.33(56.38)$ & $75.66(60.47)$ & & \\
\hline & 100 & $69.66(56.58)$ & $75.33(60.36)$ & $79.66(63.44)$ & & \\
\hline \multirow{4}{*}{$\begin{array}{l}\text { Trichoderma } \\
\text { viride }\end{array}$} & 10 & $54.00(47.29)$ & $59.66(50.65)$ & $61.66(51.74)$ & \multirow{4}{*}{$\begin{array}{c}71.77 \\
(58.22)\end{array}$} & \\
\hline & 25 & $67.33(55.15)$ & $69.66(56.69)$ & $73.66(59.13)$ & & \\
\hline & 50 & $74.00(59.35)$ & $77.66(61.81)$ & $77.33(61.59)$ & & \\
\hline & 100 & $79.00(62.75)$ & $81.66(64.69)$ & $85.66(67.75)$ & & \\
\hline \multirow{4}{*}{$\begin{array}{l}\text { Trichoderma } \\
\text { harzianum }\end{array}$} & 10 & $55.33(48.05)$ & $57.66(49.42)$ & $61.66(51.78)$ & \multirow{4}{*}{$\begin{array}{c}72.25 \\
(58.69)\end{array}$} & \\
\hline & 25 & $69.35(56.38)$ & $69.60(56.68)$ & $71.60(57.86)$ & & \\
\hline & 50 & $77.60(61.81)$ & $71.33(57.80)$ & $75.65(60.47)$ & & \\
\hline & 100 & $82.66(65.42)$ & $85.33(67.67)$ & $89.33(70.95)$ & & \\
\hline \multirow{4}{*}{$\begin{array}{l}\text { Beauveria } \\
\text { bassiana }\end{array}$} & 10 & $32.66(34.83)$ & $41.60(40.19)$ & $55.66(48.25)$ & \multirow{4}{*}{$\begin{array}{c}51.67 \\
(46.03)\end{array}$} & \\
\hline & 25 & $45.30(42.31)$ & $46.66(43.08)$ & $59.64(50.61)$ & & \\
\hline & 50 & $47.33(43.46)$ & $51.30(45.76)$ & $67.66(55.35)$ & & \\
\hline & 100 & $49.65(44.79)$ & $55.00(47.86)$ & $67.62(55.79)$ & & \\
\hline \multirow{4}{*}{$\begin{array}{l}\text { Metarhizium } \\
\text { anisopliae }\end{array}$} & 10 & $32.00(34.43)$ & $37.00(37.41)$ & $43.66(41.35)$ & \multirow{4}{*}{$\begin{array}{r}45.50 \\
(42.40)\end{array}$} & \\
\hline & 25 & $42.33(40.58)$ & $45.66(42.50)$ & $49.65(44.78)$ & & \\
\hline & 50 & $43.00(40.96)$ & $47.62(43.64)$ & $51.65(45.95)$ & & \\
\hline & 100 & $46.30(42.89)$ & $49.64(44.80)$ & $57.60(49.40)$ & & \\
\hline \multirow[t]{4}{*}{ Culture broth } & 10 & $14.00(21.83)$ & $24.00(29.23)$ & $28.30(31.93)$ & \multirow{4}{*}{$\begin{array}{c}26.72 \\
(30.86)\end{array}$} & \\
\hline & 25 & $18.00(24.93)$ & $28.00(31.93)$ & $30.00(33.14)$ & & \\
\hline & 50 & $22.00(27.95)$ & $30.00(33.19)$ & $32.40(34.39)$ & & \\
\hline & 100 & $24.00(29.32)$ & $34.00(35.65)$ & $36.00(36.82)$ & & \\
\hline $\begin{array}{l}\text { Period of } \\
\text { Exposure (t) Mean }\end{array}$ & & $52.26(46.29)$ & $57.18(49.34)$ & $62.19(52.42)$ & & \\
\hline
\end{tabular}

Figures in the parentheses are Arc-Sine transformed values 